\title{
Effects of salt stress on antioxidant and ascorbate glutathione cycle enzyme activities in Pokkali rice varieties - Vytilla 1-9
}

\author{
Lins Simon \& Yusuf $A^{*}$ \\ Inter University Centre for Plant Biotechnology, Department of Botany, University of Calicut, Kerala 673 635, India \\ *Email:akkara69@yahoo.co.in
}

\section{ARTICLE HISTORY}

Received: 12 December 2019

Accepted: 08 April 2020

Published: 01 July 2020

\section{KEYWORDS}

antioxidant enzymes

ascorbate - glutathione cycle

pokkali rice

rice

salt tolerance

\begin{abstract}
The enzymatic and non-enzymatic antioxidant levels in the released salt tolerant Pokkali, (vytilla, VTL 19) varieties were studied under different $\mathrm{NaCl}$ concentrations $(0-150 \mathrm{mM} \mathrm{NaCl})$. The specific activity of superoxide dismutase (SOD), catalase (CAT) and ascorbate-glutathione cycle enzymes and nonenzymatic antioxidants like superoxide $\left(\mathrm{O}_{2}{ }^{-}\right)$, hydrogen peroxide $\left(\mathrm{H}_{2} \mathrm{O}_{2}\right)$, malondialdehyde (MDA), glutathione (GSH) and ascorbic acid (AsA) was determined in plants exposed to salt stress. IR-28 was used as positive control and the VTL varieties were used as negative control. The $\mathrm{H}_{2} \mathrm{O}_{2}$ and superoxide $\left(\mathrm{O}_{2}{ }^{-}\right)$contents were higher in IR-28 at all the applied concentrations of $\mathrm{NaCl}$. The VTL varieties without salt treatment did not evoke any response substantiating the role of salt priming in antioxidant signalling. The MDA contents were higher in the positive and negative control. MDA content was reduced in the $\mathrm{NaCl}$ treated VTL varieties. In the positive and negative control varieties, the quantity of ascorbate and glutathione contents were lesser and upregulated in salt treated VTL varieties. Highest $\mathrm{H}_{2} \mathrm{O}_{2}$ content was observed in $150 \mathrm{mM} \mathrm{NaCl}$ treatment. The $\mathrm{H}_{2} \mathrm{O}_{2}$ contents decreased with the increase in all concentrations of $\mathrm{NaCl}$ and lowest $\mathrm{H}_{2} \mathrm{O}_{2}$ contents was observed in VTL-1 and highest in VTL-2 and VTL-8 treated with $150 \mathrm{mM} \mathrm{NaCl}$. Superoxide contents varied in all the nine varieties depending on the salt concentration. The SOD levels in all the varieties showed a positive correlation with the superoxide and $\mathrm{H}_{2} \mathrm{O}_{2}$ content. Lesser quantities of SOD, CAT and the ascorbate - glutathione cycle enzymes were expressed in the positive and negative control. The increased $\mathrm{NaCl}$ concentration (25-150 mM) upregulated antioxidant and ascorbate-glutathione cycle enzymes in the VTL varieties. The APX activity was lower in the control and salt treated plants. The GR activity increased linearly in all the varieties with respect to salt concentrations. The MDHAR and DHAR activities showed marginally linear increase, with all concentrations of $\mathrm{NaCl}$. The APX activity was similar or lower to MDHAR activity while DHAR activity was similar to MDHAR activity. The results of the present study reveals the higher levels of enzymatic and non-enzymatic antioxidants under salt stress reflect the salt tolerance potential of pokkali varieties mediated by the up regulation of ROS scavenging enzymes.
\end{abstract}

\section{Introduction}

Rice (Oryza sativa L.) is one of the important cereal crops throughout the world. The global climate change is reducing the productivity by increasing salinity in agricultural land by about $50 \%$ (1). In this context, food security issues can be addressed by developing salt tolerant varieties of rice suitable for arid, semi-arid and waterlogged regions. Kerala has a long coastal area of about $580 \mathrm{~km}$, which has several lagoons and backwaters covering a very large area linked to the sea. The deltaic regions are either at the sea level or below affecting the intrusion of sea water to agriculture lands (2). The salt tolerance mechanism is obscure in most of the salt tolerant rice varieties developed through conventional breeding techniques. The survival of plants in high salt habitat is depending on the production of reactive oxygen species (ROS) and highly efficient scavenging of this anion by the antioxidant and ascorbate-glutathione cycle enzymes. The production of ROS, the by-product of

(c) Simon \& Yusuf (2020). This is an open-access article distributed under the terms of the Creative Commons Attribution License, which permits unrestricted use, distribution, and reproduction in any medium, provided the original author and source are credited (https://creativecommons.org/licenses/by/4.0/).

To cite this article: Simon L, Yusuf A. Effects of salt stress on antioxidant and ascorbate glutathione cycle enzyme activities in Pokkali rice varieties - Vytilla 1-9. Plant Science Today. 2020;7(3):341-348. https://doi.org/10.14719/pst.2020.7.3.701 
oxidative metabolism in plants causes damage to DNA, proteins and chlorophyll etc. (3-5). It is enhanced in response to abiotic stresses like drought $(6,7)$, elevated temperature (8) and xenobiotics (9).

Studies suggest that antioxidant enzymes are upregulated in plants exposed to abiotic stress (10). Charged superoxide radical cannot move freely across the membranes, hence the subcellular compartmentalisation of the antioxidant system is necessary for efficient quenching of this anion and its immediate product $\mathrm{H}_{2} \mathrm{O}_{2}$, at the site of production. Synchronous action of superoxide dismutase (SOD), catalase (CAT) and ascorbateglutathione cycle enzymes, ascorbate peroxidase (APX), monodehydroascorbate reductase (MDHAR), dehydroascorbate reductase (DHAR), glutathione reductase (GR) is responsible for quenching of AOS $(11,12)$. APX uses the reduced ascorbate as a reductant in the first reaction of ascorbate glutathione cycle, is the most important peroxidase in detoxifying $\mathrm{H}_{2} \mathrm{O}_{2}$ (13). Correlation between the ascorbate-glutathione cycle enzymes and salt tolerant is compared in the sensitive and resistant varieties of rice (14). However, the salt tolerance capacity of the pokkali rice variety, vytilla (VTL) with respect to the antioxidant and ascorbateglutathione cycle enzymes is not investigated so far. The present study was undertaken to evaluate the salt tolerance capacity and the levels of antioxidant and ascorbate-glutathione cycle enzymes in the released pokkali rice varieties, vytilla (VTL) 1-9 (negative control) and IR-28 variety (positive control) under different salt concentrations. This study will help in understanding the ROS scavenging mechanism and the adaptation to salt stress in these released varieties.

\section{Materials and Methods}

\section{Plant materials}

Seeds of the released Pokkali rice varieties (VTL 19), were collected from Rice Research station, Kerala Agriculture University, Vytilla, Kerala while, IR-28 seeds were obtained from Rice Research Station, Pattambi, Kerala.

\section{Experimental design}

The experiment was set up in a completely randomized design in 7 tanks filled equal volume of water containing $\mathrm{NaCl}$ concentrations of 0,25 , 50, 75, 100, 125 and $150 \mathrm{mM}$. The seeds were germinated in seed beds. Twenty-one day old seedlings were planted in pots containing a soil mixture comprising of loam soil and cow dung mixture in the ratio $1: 1$. Three replications were performed, each containing 10 seedlings. $\mathrm{NaCl}$ treatment started on $25^{\text {th }}$ day of germination by incrementing $25 \mathrm{mM}$ per day to attain a final concentration of $150 \mathrm{mM}$. One set of plantlets were kept as control without $\mathrm{NaCl}$ application and watered with tap water. Leaf samples for the enzyme assay were harvested after 21 days (46 days from seed germination) of salt application and frozen in Liquid Nitrogen $\left(\mathrm{LN}_{2}\right)$ and stored at $-80^{\circ} \mathrm{C}$.

\section{Quantification of ROS and non-enzymatic antioxidants}

The superoxide radical $\left(\mathrm{O}_{2}^{-}\right)$was determined (15). A standard curve was prepared with nitrogen dioxide $\left(\mathrm{NO}_{2}\right)$ to calculate the $\mathrm{O}_{2}^{-}$generation rate. Hydrogen peroxide $\left(\mathrm{H}_{2} \mathrm{O}_{2}\right)$ content was determined (16). The lipid peroxidation was determined using malondialdehyde (MDA) content as per standard method (17). The concentration of the MDA/TBA (malondialdehyde/thiobarbituric acid) complex was calculated and the level of lipid peroxidation was determined.

Ascorbic acid (AsA) content was assayed using the protocol (18). Optical density was recorded at $525 \mathrm{~nm}$. A standard curve was prepared using a gradient concentration of AsA.

Total and reduced glutathione were determined using previously described protocol (19). The GSH concentration was calculated using a standard curve prepared using gradient concentrations of GSH. The spectrophotometric reading was taken at $412 \mathrm{~nm}$. The quantity of GSSG is determined using the formula, GSSG = Total GSH $-\mathrm{GSH}$.

\section{Quantification of enzymatic antioxidants}

Superoxide dismutase (SOD) and catalase (CAT) was extracted from the frozen sample $(0.5 \mathrm{~g})$, homogenized in $\mathrm{LN}_{2}$ by adding $100 \mathrm{mM}$ phosphate buffer ( $4 \mathrm{ml}, \mathrm{pH} 7.0), 1 \mathrm{mM}$ EDTA $(16 \mu \mathrm{l})$ and 1\% (w/ v) polyvinyl pyrrolidone (PVP). The homogenate was centrifuged at $10000 \mathrm{rpm}$ for $15 \mathrm{~min}$ at $4{ }^{\circ} \mathrm{C}$ and the supernatant was collected for further studies. Ascorbate peroxidase (APX) was extracted from the leaf sample $(0.5 \mathrm{gm})$ homogenized in extraction medium containing $50 \mathrm{mM}$ potassium phosphate buffer (pH 7.0), 1 mM EDTA, 2\% (w/v) PVP and $1 \mathrm{mM}$ ascorbic acid. The homogenate was centrifuged at $15000 \mathrm{rpm}$ for $20 \mathrm{~min}$ at $4{ }^{\circ} \mathrm{C}$. For the glutathione reductase (GR) assay, the sample $(0.5$ gm) was powdered in $\mathrm{LN}_{2}$, homogenized in $100 \mathrm{mM}$ potassium phosphate buffer ( $\mathrm{pH}$ 7.8) containing 2 $\mathrm{mM}$ EDTA and $1 \%(\mathrm{w} / \mathrm{v})$ PVP-40 at $4{ }^{\circ} \mathrm{C}$. The homogenate was centrifuged at $15000 \mathrm{rpm}$ for 20 $\min$ at $4{ }^{\circ} \mathrm{C}$ and the supernatant was collected. Monodehydroascorbate reductase (MDHAR) and dehydroascorbate reductase (DHAR) was assayed using powdered plant sample $(0.5 \mathrm{~g})$ homogenized in $50 \mathrm{mM}$ potassium phosphate buffer ( $\mathrm{pH}$ 7.8) and $1 \mathrm{mM}$ EDTA. Homogenate was centrifuged at 14000 rpm for $20 \mathrm{~min}$ at $4{ }^{\circ} \mathrm{C}$ and the supernatant was used for enzyme assay.

Superoxide dismutase (SOD, EC 1.15.1.1) activity was measured according to the modified protocol (20). One unit SOD was calculated as the enzyme activity required for $50 \%$ photoreduction of nitrobluetetrazolium to blue formazan.

Catalase (CAT; EC 1.11.1.6) activity was measured (21). Change in absorbance at $240 \mathrm{~nm}$ due to the degradation of $\mathrm{H}_{2} \mathrm{O}_{2}$ was recorded at an interval of $15 \mathrm{~s}$ for $2 \mathrm{~min}$. 
Ascorbate peroxidase (APX; EC 1.11.1.11) activity was measured (22). The decrease in absorbance due to ascorbate oxidation was recorded at $290 \mathrm{~nm}$ at $15 \mathrm{~s}$ intervals for $2 \mathrm{~min}$. The specific activity was calculated and expressed as $\mu$ mole mg protein ${ }^{-1} \mathrm{~min}^{-1}$.

Glutathione reductase (GR; EC 1.11.1.9) activity was determined (23) with some modifications. Change in absorbance at $412 \mathrm{~nm}$ due to the oxidation of NADPH was recorded in 15-s intervals for $2 \mathrm{~min}$ and the specific activity of the enzyme was calculated and expressed as $\mu$ mole mg protein ${ }^{1} \mathrm{~min}^{-1}$.

Monodehydroascorbate reductase (MDHAR; EC 1.6.5.4) and Dehydroascorbate reductase (DHAR; EC,1.6.5.4) activities were assayed (24). The decrease in absorbance in MDHAR was monitored at $340 \mathrm{~nm}$ owing to the oxidation of NADH while, DHAR activity was determined by monitoring the rate of AsA formation at $265 \mathrm{~nm}$.

Total protein from the experimental samples was determined (25). The absorbance was measured at $660 \mathrm{~nm}$ using a UV-VIS spectrophotometer and the protein were quantified using gradient concentrations of BSA (1.0 mg/l).

\section{Statistical analysis}

All the enzymatic and non-enzymatic assays were repeated thrice and the data was subjected to analysis of variance ( $p \leq 0.05)$ and the mean values were compared using ANOVA.

\section{Results}

\section{Quantification of ROS contents}

The superoxide $\left(\mathrm{O}_{2}^{-}\right)$contents in the VTL varieties increased proportionate to the $\mathrm{NaCl}$ concentration (Fig. 1A). In the positive control IR-28, the $\mathrm{O}_{2}{ }^{-}$ content was 8-10 times higher compared to the tolerant varieties. Among the Pokkali varieties, VTL-4 showed lesser $\mathrm{O}_{2}^{-}$content and VTL-9 showed the highest levels of $\mathrm{O}_{2}^{-}$in all the concentrations of $\mathrm{NaCl}$ used. The varieties VTL-4, VTL-5, VTL-6 and VTL-7 showed a decrease in $\mathrm{O}_{2}^{-}$content with increase in $\mathrm{NaCl}$ concentration. All the other varieties showed a steady increase in $\mathrm{O}_{2}^{-}$content proportionate with $\mathrm{NaCl}$ concentration. The positive control IR-28 produced 3-4 times higher $\mathrm{H}_{2} \mathrm{O}_{2} \quad\left(0.789 \pm 0.08 \mathrm{mMol} \mathrm{g}^{-1}\right)$ compared to salt tolerant Pokkali varieties (Fig. 1B). The $\mathrm{H}_{2} \mathrm{O}_{2}$ content in the negative control VTL varieties were lesser compared to salt treated VTL varieties. During $\mathrm{NaCl}$ treatment the highest $\mathrm{H}_{2} \mathrm{O}_{2}$ content was observed in VTL-2 $\left(0.267 \mathrm{mMol} \mathrm{g}^{-1}\right)$ and the lowest quantity was observed in VTL-4 (0.188 mMol $\mathrm{g}^{-1}$ ) in $150 \mathrm{mM} \mathrm{NaCl}$. All the other varieties showed an increase in the $\mathrm{H}_{2} \mathrm{O}_{2}$ content upon exposure to $\mathrm{NaCl}$, however, the response was dependent on $\mathrm{NaCl}$ concentration and time of exposure.

\section{MDA content}

The MDA quantity was higher $\left(0.712 \mathrm{mMol} \mathrm{g}^{-1}\right)$ in the positive control IR-28 (Fig. 1C). The salt tolerant VTL varieties used as negative control produced lesser quantity of $\mathrm{MDA}$ in $150 \mathrm{mM} \mathrm{NaCl}$. Higher MDA content was observed in the salt treated VTL varieties comparing to IR-28 and a maximum quantity was observed in VTL-9 (0.502 $\left.\mathrm{mMol} \mathrm{g}^{-1}\right)$. The lowest quantity in VTL-3 $\left(0.323 \mathrm{mmolg}^{-1}\right)$ treated with $150 \mathrm{mM} \mathrm{NaCl}$ on the $21^{\text {st }}$ day.

\section{Ascorbic acid (AsA) content}

The AsA content in the positive control IR-28, sharply declined with increasing in $\mathrm{NaCl}$ concentration and duration of $\mathrm{NaCl}$ exposure (Fig. 1D). In the negative control, the VTL varieties produced higher AsA, while VTL varieties under salt stress maintained steady level of AsA. Among the VTL varieties, the highest AsA content was observed in VTL-2 $\left(0.928 \mathrm{mmolg}^{-1}\right)$ and the lowest in VTL-8 $\left(0.667 \mathrm{mmolg}^{-1}\right)$. The AsA content decreased proportionate with the increase in $\mathrm{NaCl}$ concentration and the duration of exposure.

\section{GSH contents and GSH/GSSG ratio}

The GSH contents in the positive control IR-28 was lesser compared to the negative control VTL varieties (Fig. 1E). In the salt treated varieties, the higher quantity of glutathione was measured in VTL-1 treated with $150 \mathrm{mM} \mathrm{NaCl}$ on the $21^{\text {st }}$ day. The GSH/GSSG ratio (Fig. 1F) decreased with increase in $\mathrm{NaCl}$ concentration suggesting the presence of a higher quantity of oxidised glutathione.

\section{SOD activity}

The SOD activity was upregulated on exposure to different concentrations of $\mathrm{NaCl}$. The highest SOD activity was expressed in $150 \mathrm{mM} \mathrm{NaCl}$ treated VTL2 with $43.99 \pm 4.36 \mathrm{U}$ SOD $\mathrm{mg}$ protein ${ }^{-1}$. In rest of the varieties the SOD activity was upregulated and showed consistent increase with increase in salt concentration. In the control experiment, the variety VTL-9 showed the highest SOD activity of $21.34 \pm 1.38$ U SOD mg protein ${ }^{-1}$ followed by VTL8 > VTL7 > VTL6 > VTL1 > VTL5 > VTL2 > VTL4 > VTL3 (Fig. 2A). In the positive control IR-28, the SOD expression decreased with increasing $\mathrm{NaCl}$ concentration and duration of exposure.

\section{Catalase activity}

Catalase activity in the salt treated VTL varieties followed the same pattern of SOD, though the expression level varies, the highest enzyme activity was observed in VTL-1 treated with $150 \mathrm{mM} \mathrm{NaCl}$ with a specific activity of $0.506 \pm 0.0087 \mu$ mole $\mathrm{mg}$ protein ${ }^{-1} \mathrm{~min}^{-1}$ and in the negative control plants, the CAT activity was lesser than the salt treated varieties. The salt treated varieties showed an increased CAT activity in all the concentrations of $\mathrm{NaCl}$ used, though the enzyme activity varied slightly in salt treatment (Fig. 2B). The CAT activity in the positive control IR-28, was approximately 4-6 times lesser than the salt treated varieties.

\section{APX activity}

In the control experiment, highest APX specific activity was measured in VTL-6 $(0.249 \pm 0.018 \mu$ mole $\mathrm{mg}$ protein $\left.{ }^{-1} \mathrm{~min}^{-1}\right)$. The other varieties showed almost similar APX activity upregulated in response to salt concentration and the specific activity increased proportionate with the salt concentration. The 
highest specific activity $(0.527 \pm 0.018 \mu$ mole $\mathrm{mg}$ protein ${ }^{-1} \mathrm{~min}^{-1}$ ) was observed in $150 \mathrm{mM} \mathrm{NaCl}$ treated VTL-3 and the lowest in VTL-7. The specific activity of APX in all the varieties treated with different concentrations of $\mathrm{NaCl}$ is shown in (Fig. 2C). The APX activity in the positive control (IR28) showed lesser activity of APX in all the concentrations of $\mathrm{NaCl}$ used.

\section{GR activity}

The highest GR activity $(0.274 \pm 0.006 \mu$ mole $\mathrm{mg}$ protein $^{-1} \mathrm{~min}^{-1}$ ) was observed in VTL-1 compared to the other varieties in the negative control. Among the salt stressed varieties the highest GR activity of $0.553 \pm 0.008 \mu$ mole $\mathrm{mg}$ protein ${ }^{-1} \mathrm{~min}^{-1}$ was observed in VTL-1, grown in $150 \mathrm{mM} \mathrm{NaCl}$. All the other varieties expressed an increased GR activity expressing concentrations and varietal differences (Fig. 2D). In the positive control IR-28 the GR activity was 5-7 times lesser than the VTL varieties.

\section{MDHAR activity}

In the negative control, the variety VTL-3 showed the highest MDHAR activity of $1.19 \pm 0.02 \mu$ mole $\mathrm{mg}$ protein $^{-1} \mathrm{~min}^{-1}$. In the salt treatments the highest MDHAR activity was observed in VTL-2 with a specific activity of $1.67 \pm 0.49 \mu$ mole $\mathrm{mg}_{\text {protein }}{ }^{-1} \mathrm{~min}^{-1}$. The MDHAR activity in the salt stressed and control did not show much difference, except in VTL-2 and VTL-6 suggesting that the Pokkali varieties used for the study have high inherent MDHAR activity (Fig. 2E). The positive control, IR-28 showed 2-3 times lesser MDHAR activity compared to the VTL varieties treated with different concentrations of $\mathrm{NaCl}$.

\section{DHAR activity}

In the negative control, the variety VTL-2 expressed the highest DHAR activity of $1.19 \pm 0.08 \mu$ mole $\mathrm{mg}$ protein $^{-1} \mathrm{~min}^{-1}$. The DHAR activity was upregulated in salt treated varieties and the highest DHAR activity was observed in $150 \mathrm{mM} \mathrm{NaCl}$ treated VTL-6 variety with an enzyme activity of $1.30 \pm 0.015 \mu$ mole mg protein $^{-1}$ min $^{-1}$ (Fig. 2F). The positive control IR-28 showed 2-3 times lesser DHAR activity compared to the salt treated VTL- varieties.

\section{Discussion}

The salt tolerant Pokkali varieties, (Vyttila-1-9) developed through conventional breeding methods, were capable of constitutive activation of peroxide scavenging pathways in order to adapt to salt stress. This suggests that the salt tolerant pathways were initiated by scavenging the stress related compounds, thus maintaining a stable $\mathrm{Na}^{+} / \mathrm{K}^{+}$ratio in plants (26). Under salt stress conditions, VTL varieties produced lesser quantity of $\mathrm{H}_{2} \mathrm{O}_{2}$ compared to other pokkali varieties like CSR-1 (27) and positive control IR-28 suggesting the adaptability of the VTL varieties to salt stress. The reduced $\mathrm{H}_{2} \mathrm{O}_{2}$ in the salt tolerant varieties is related to the upregulation of SOD and CAT activity that assist in scavenging the generated $\mathrm{H}_{2} \mathrm{O}_{2}$. The increased $\mathrm{O}_{2}^{-}$contents in the negative control plants suggest the inherent capacity of the salt tolerant Pokkali varieties in alleviating salt stress. However, the superoxide radical emissions were dependent on $\mathrm{NaCl}$ concentration. Over production of ROS during salt stress leads to the toxicity in cells causing cellular damages. The incidence of salinity stress in plants produces ROS and several adverse effects that have a destructive influence on different plant processes (28). In accordance with the prevention from oxidative damage caused due to lipid peroxidation, plants have developed specific strategies comprising upregulation of specific enzyme pathways, metabolite production and gene expression (29). Plants strongly control the production and elimination of ROSs by many enzymatic and nonenzymatic processes to the alleviation of their damages (30). These non- enzymatic and enzymatic antioxidants play a vital role by interacting with each other in order to scavenge the reactive oxygen species mediated by the over expression of different genes and thus helping the plants to acclimatise to the adverse environmental conditions $(31,32)$. MDA content is considered as a sign of the extent of oxidative damage under stress conditions (33). Higher quantity of MDA in the negative and positive control during salt stress suggested membrane peroxidation and the MDA content did not show any upregulation, thus preventing the lipid peroxidation; congruent results are reported in Beta maritima, a salt tolerant variety during salt stress (34). Ascorbate content in the positive and negative control were upregulated, whereas in the salt tolerant varieties, the AsA content decreased in the VTL varieties attributing the up regulated activity of the APX enzyme which utilises ascorbate. It may also possible that the reduced AsA content can be due to the increased catabolism of the reduced or oxidised ascorbate. The two fold increase in GSH content in the salt stressed VTL varieties is related to the higher levels of GSH synthesis and the considerable increase in GR activity that assists in maintaining the GSH/GSSG ratio, the decrease in the GSH/GSSG ratio specifies the oxidative stress related cellular redox buffer under salt stress.

The upregulated SOD and CAT activities in the VTL varieties suggests that the superoxide radical generation due to salt stress is also alleviated by the participation of NADPH and the signalling cascade involving the ascorbate glutathione cycle enzymes that help to scavenge the ROS. Combined action of SOD and CAT in alleviating the stress responses were reported in other plant species (35). The $\mathrm{H}_{2} \mathrm{O}_{2}$ dependant oxidation of AsA is active in the tolerant varieties and the upregulation of APX specific activity suggest that, the $\mathrm{H}_{2} \mathrm{O}_{2}$ produced in the tolerant plants during salt stress is effectively scavenged through the ascorbate-glutathione cycle enzymes. The upregulated activity of CAT and APX enzymes also suggests that the competition for the substrate $\mathrm{H}_{2} \mathrm{O}_{2}$ is not affecting the activity of these enzymes as reported earlier (14).

Catalase is one of the $\mathrm{H}_{2} \mathrm{O}_{2}$ detoxifying enzymes which is mostly associated with peroxisomes and helps in removing $\mathrm{H}_{2} \mathrm{O}_{2}$ formed during photorespiration. The differential behaviour of these cultivars on time scale indicates the early adaptive potential of Pokkali in terms of CAT activity. The upregulation of $\mathrm{H}_{2} \mathrm{O}_{2}$ and CAT activity is correlated with the increased protection from the damage associated with oxidative stress (4, 36). This 


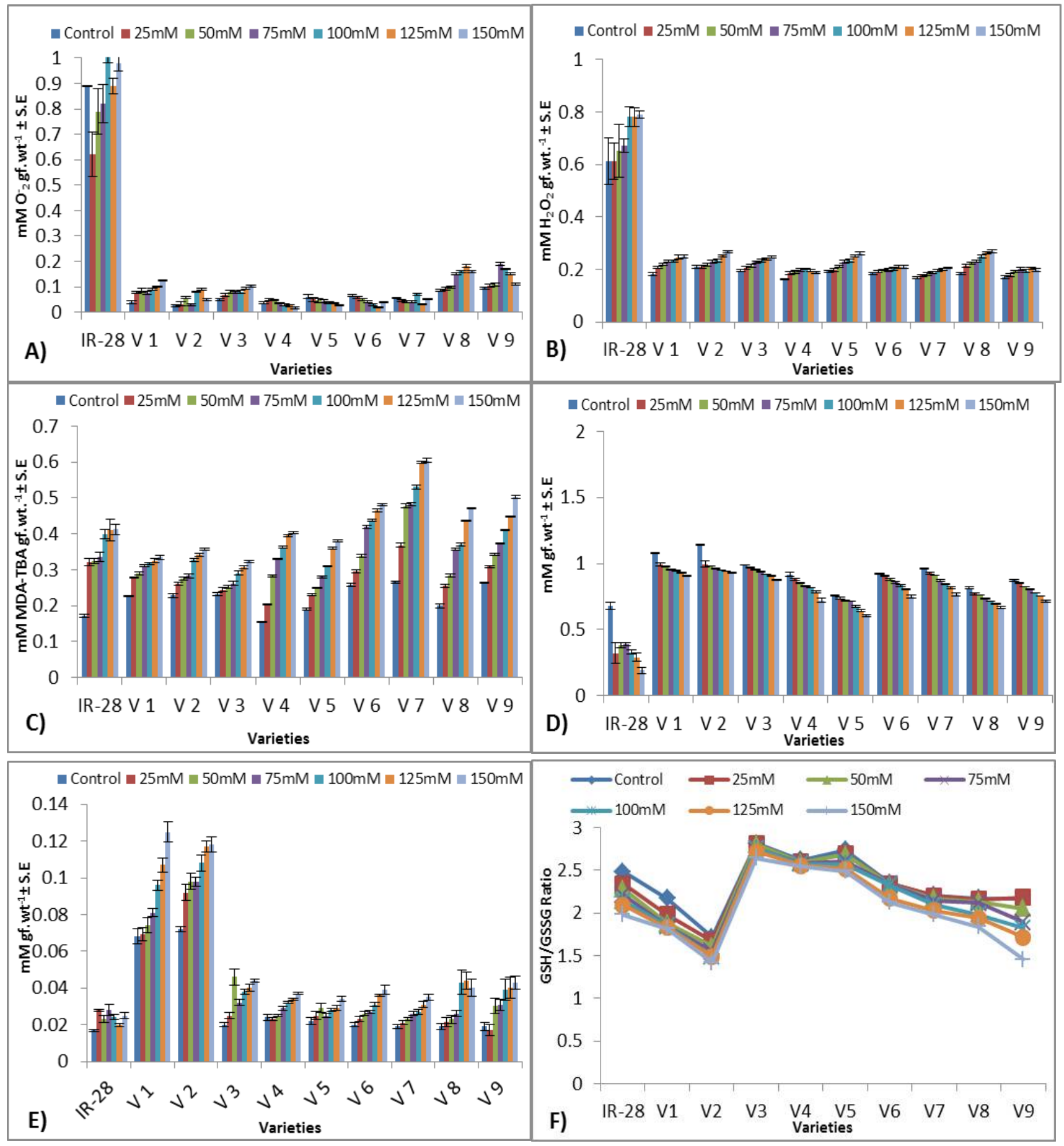

Fig. 1. A) Superoxide content, B) Hydrogen peroxide content, C) MDA content, D) Ascorbate content, E) Glutathione content, F) GSH/GSSG ratio in the IR-28 and VTL varieties treated with different concentrations of $\mathrm{NaCl}$ on the $21^{\text {st }}$ day. The values are the mean of three independent experiments and are subjected to one-way ANOVA. The values are significant at $\mathrm{p}=>5$.

corroborates the significant differences in the CAT activity of the salt tolerant and salt-sensitive cultivars of pea reported during salt stress (37). The upregulated APX activity suggests that the VTL varieties develop inherent characteristics for protection against salt stress by maintaining the $\mathrm{H}_{2} \mathrm{O}_{2}$ concentration inside the cell to a non-toxic level as the combined activities of APX and CAT are responsible for $\mathrm{H}_{2} \mathrm{O}_{2}$ scavenging (38). APX is one of the most important antioxidant enzymes in plants that detoxify $\mathrm{H}_{2} \mathrm{O}_{2}$ using ascorbate as reductant. It exists in several isoforms in various compartments of plant cells and shows differential expression and regulation under environmental stress factors. In the
VTL varieties, the APX activity decreased without salt treatment, however, the SOD to APX activity differed significantly in the different VTL varieties. The higher ratio of SOD to APX correlate with $\mathrm{H}_{2} \mathrm{O}_{2}$ scavenging, suggesting that in the VTL varieties the $\mathrm{H}_{2} \mathrm{O}_{2}$ produced is actively detoxified.

Glutathione reductase (GR) is essential for the elimination of ROS and for the maintenance of reduced glutathione (GSH) by the ascorbate/glutathione cycle. The enzyme GR mediates the reduction of oxidized glutathione (GSSG) produced by the action of DHAR, which in turn produced by the APX during the peroxidation of 


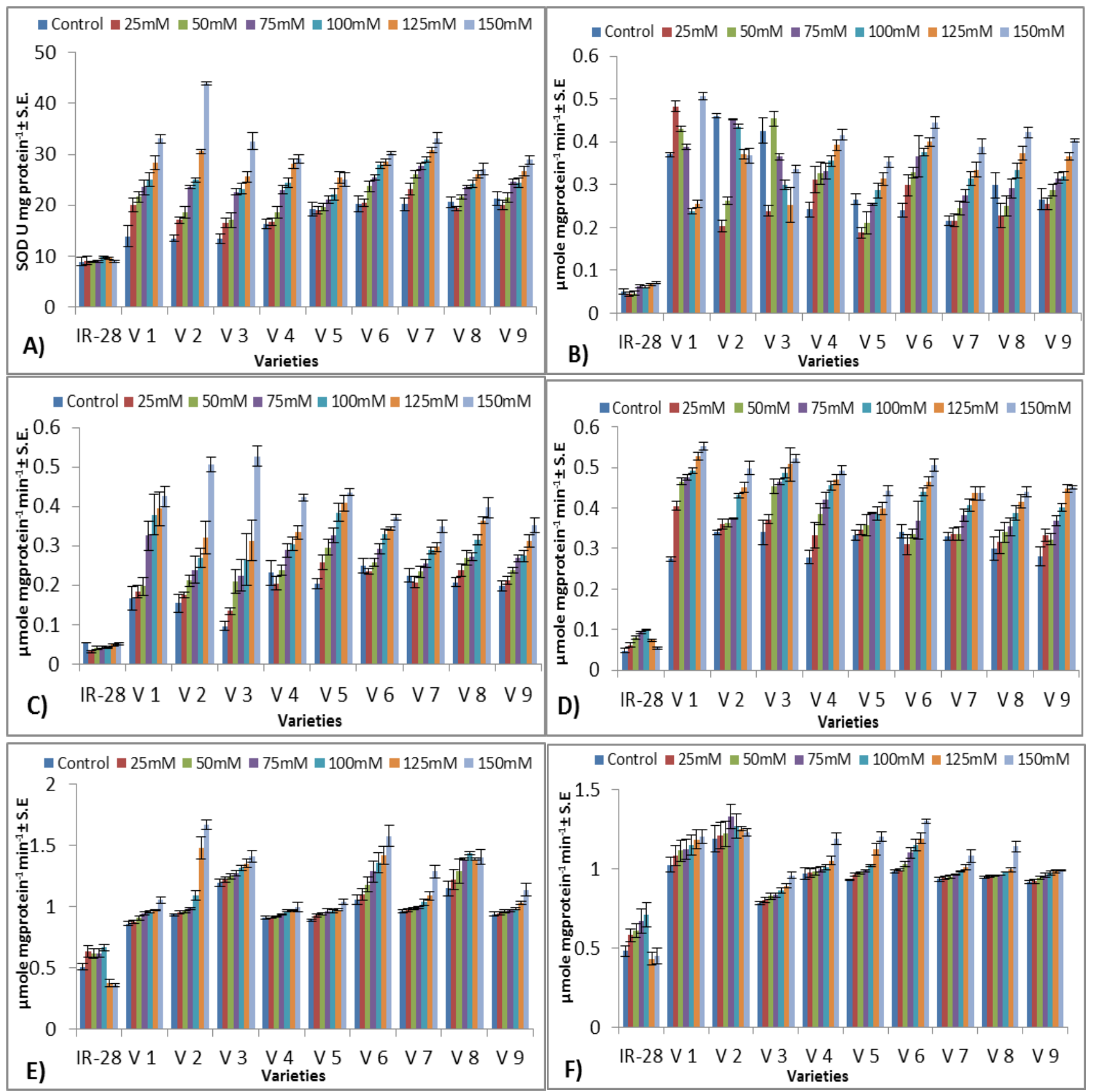

Fig. 2. A) Superoxide dismutase activity, B) Catalase activity, C) Ascorbate peroxidase activity, D) Glutathione reductase activity, E) Monodehydroascorbate reductase activity, F) Dehydroascorbate reductase activity in the IR-28 and vytilla varieties treated with different concentrations of $\mathrm{NaCl}$ on the $21^{\text {st }}$ day. The values are the mean of three independent experiments and are subjected to one-way ANOVA. The values are significant at $p=>5$.

ascorbate, to the reduced GSH pool using NADPH as an electron donor. Thus, a highly reduced state of GSH/GSSG ratio is maintained at the intracellular level by this reaction during oxidative stress. It was observed that the activity of GR increase linearly to the salt concentration in all the VTL varieties compared to negative control VTL varieties. These results are in corroboration with the earlier results that GR activity increases during salt treatment in order to generate glutathione, an intracellular nonenzymatic antioxidant that protects the plant membranes and prevents the oxidative denaturation of proteins under stress by protecting their thiol groups (39).

MDHAR is the major enzyme in AsA-GSH cycle contributing to ASC generation and the APX and
MDHAR activities are higher or the MDHAR activity is one order of magnitude lower than the APX activity and the DHAR activity one order lesser than MDHAR activity under salt stress in most of the plant species (40). The results obtained in VTL varieties under salt stress suggest that the capacity to regenerate ASC was similar or higher than the capacity of APX to oxidise MDA. The lower activities of GR and DHAR support this view. The increased MDHAR activity in the salt stressed VTL varieties compared to negative control VTL varieties suggest the higher capacity of ASC generation under salt stress conditions. As observed in some other plants, the decreased MDHAR activity in the negative control suggests the level of ascorbate regeneration can be correlated with salt concentration among VTL varieties (41, 42). Furthermore, the higher activity of various 
antioxidant enzymes (SOD, CAT, APX, MDHAR, DHAR and GR) in a coordinated manner in the salt tolerant cultivars suggests that they are the major determinants in elucidating salt tolerance.

The Pokkali varieties (VTL-1-9) could not withstand $\mathrm{NaCl}$ concentration above $150 \mathrm{mM}$ as the $\mathrm{NaCl}$ treated plants turn yellow from the $25^{\text {th }}$ day of salt treatment, indicating the tolerance threshold of $150 \mathrm{mM}$ for these varieties. Most of the studies conducted on salt tolerance in rice varieties were based on salt treatment for 24-48 hrs (14, 43), however, the present study, the salt tolerance upto 30 days in 75 day old plants with $25-150 \mathrm{mM} \mathrm{NaCl}$ provide conclusive results on the salt tolerance potential of these varieties. The negative control VTL varieties, the quantity of antioxidant enzymes match with the salt treated varieties, demonstrating that the salt tolerant varieties have inherently higher expression of antioxidant enzymes.

\section{Authors' contributions}

LS carried out the enzyme assays and prepared the first draft of the manuscript. AY conceived of the research idea designed the experiments and edited the manuscript. All authors read and approved the final manuscript.

\section{Acknowledgements}

The authors are grateful to the Director, Interuniversity Centre for Plant Biotechnology for providing facilities and support. Financial support from Kerala State Council for Science Technology and Environment for this study under the SRS scheme No. 001/SRSLS/2013/CSTE is acknowledged.

\section{Conflict of interest}

The authors declare that they have no conflict of interests.

\section{References}

1. Song T, Zhang Q, Wang H, Han J, Xu Z, Yan S, Zhu Z. OsJMJ703, a rice histone demethylase gene, plays key roles in plant development and responds to drought stress. Plant Physiology

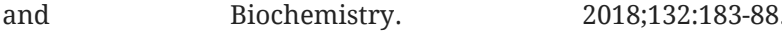
https://doi.org/10.1016/j.plaphy.2018.09.007

2. Jayan PR, Sathyanathan N. Overview of farming practices in the water-logged areas of Kerala, India. International Journal of Agricultural and Biological Engineering. 2010;3(4),28-43. https://doi.org/10.3965/j.issn.1934-6344.2010.04.018-03

3. Del Rio LA, Corpas FJ, Sandaliyo LM, Palma JM, Gomez M, Borroso JB. Reactive oxygen species, antioxidant systems and nitric oxide in peroxisomes. J Exp Bot. 2002;53(372):1255-72. https://doi.org/10.1093/jexbot/53.372.1255

4. Levine A. Oxidative stress as a regulator of environmental response in plants In: Lerner H.R. (editor). Plant Responses to Environmental Stresses from Phytohormones to Genome reorganisation. Marcel Dekker Inc., New York, NY. 1999;24764. https://doi.org/10.1201/9780203743157-11

5. Asada K. Radical production and scavenging in chloroplasts. In: Baker N.R. (editor) Photosynthesis and Environment.
Kluwer Academic Publisher, Dordrecht, The Netherlands. 1996;123-50. https://doi.org/10.1007/0-306-48135-9_5

6. Yu Q, Rengel Z. Drought and salinity differentially influence activites of superoxide dismutase in narrow leafed lupins. Plant Sci. 1999;142:1-11. https://doi.org/10.1016/S01689452(98)00246-5

7. Smirnoff $\mathrm{N}$. The role of active oxygen in response of plants to water deficit and desiccation. New Phytol. 1993;125:27-58. https://doi.org/10.1111/j.1469-8137.1993.tb03863.x

8. Prasard TK, Anderson MD, Martin BA, Stewart CR. Evidence for chilling -induced oxidative stress in maize seedlings and a regulatory role for hydrogen peroxide. Plant Cell. 1994;6:65-74. https://doi.org/10.1105/tpc.6.1.65

9. Bowler C, Van Montagu M, Inze D. Superoxide dismutase and stress tolerance. Annu Rev Plant Physiol. Plant Mol Biol. 1992;43:83-116.

https://doi.org/10.1146/annurev.pp.43.060192.000503

10. Foyer $\mathrm{CH}$, Noctor G. Oxygen processing in photosynthesis: Regulation and signalling. New Phytol. 2000;146:359-388. https://doi.org/10.1046/j.1469-8137.2000.00667.x

11. Rossatto T, do Amaral MN, Benitez LC, Vighi IL, Braga EJB, de MagalhaesJúnior A M, da Silva Pinto L.Gene expression and activity of antioxidant enzymes in rice plants, cv. BRS AG, under saline stress. Physiology and Molecular Biology of Plants. 2017;23(4):865-75. https://doi.org/10.1007/s12298-0170467-2

12. Guo WL, Chen RG, Gong ZH, Yin YX,Ahmed SS, He YM Exogenous abscisic acid increases antioxidant enzymes and related gene expression in pepper (Capsicum annuum) leaves subjected to chilling stress. Genet. Mol. Res. 2012;11(4):4063-80. http://dx.doi.org/10.4238/2012.September.10.5

13. Mittova V, Tal M, Volokita M, Guy M. Up regulation of the leaf mitochondrial and peroxisomal antioxidant systems in response to salt-induced oxidative stress in the wild salttolerant tomato species Lycopersicon pennellii. Plant cell and Environ. 2003;26:845-56. https://doi.org/10.1046/j.13653040.2003.01016.x

14. Kaur N, Dhawan M, Sharma I, Pati PK. Interdependency of Reactive Oxygen Species generating and scavenging system in salt sensitive and salt tolerant cultivars of rice. BMC Plant Biology. 2016;16:131. https://doi.org/10.1186/s12870-016-0824-2

15. Li C, Bai T, Maa F, Hana M. Hypoxia tolerance and adaptation of anaerobic respiration to hypoxia stress in two Malus $\begin{array}{lll}\text { species. } & \text { SciHortic. } & \text { 2010;124:274-79 }\end{array}$ https://doi.org/10.1016/j.scienta.2009.12.029

16. Velikova V, Yordanov I, Edreva A. Oxidative stress and some antioxidant systems in acid rain-treated bean plants. Plant Sci. 2000;151:59-66. https://doi.org/10.1016/S0168-9452(99)00197-1

17. Stewart RR, Bewley JD. Lipid peroxidation associated with accelerated aging of soybean axes. Plant Physiology. 1980;65(2):245-48. https://doi.org/10.1104/pp.65.2.245

18. Chen JX, Wang XF. Guide to plant physiological experiments. Guangehou: South China University of Technology Press. 2002;pp.123-27.

19. Srivastava SK, Beutler E. Accurate measurement of oxidized glutathione content of human, rabbit and rat red blood cells and tissues. Analytical Biochemistry. 1968;25,70-76. https://doi.org/10.1016/0003-2697(68)90082-1

20. Giannopolitis CN, Ries KS. Superoxide Dismutases II Purification and quantitative relationship with water-soluble protein in seedlings. Plant Physiol. 1977;59(2):315-18. https://doi.org/10.1104/pp.59.2.315

21. Aebi H. Catalase. In: Bergmeies H (editor), Methods of enzyme analysis. ChemieWenhein, Verlag. 1983; 273-77.

22. Nakano Y, Asada K. Hydrogen peroxide is scavenged by ascorbate specific peroxidase in spinach chloroplasts. Plant Cell 1981;22:867-80. https://doi.org/10.1093/oxfordjournals.pcp.a076232

23. Smith IK, Vierheller TL, Thorne CA. Assay of glutathione reductase in crude tissue homogenates using 5, 5' dithiobis (2- 
nitrobenzoic acid). Ann Biochem. 1988;175:408-13 https://doi.org/10.1016/0003-2697(88)90564-7

24. Hossain NA, Asada K. Purification of dehydro ascorbate reductase from spinach and its characterization as a thiol enzyme. Plant and Cell Physiol. 1984;25:85-92. https://doi.org/10.1093/oxfordjournals.pcp.a076700

25. Lowry OH, Rosebrough NJ, Farr AL, Randall RJ. Protein measurement with the Folin phenol reagent. J Biol Chem. 1951;193:265-75.

26. Shabala $S$, Wua $H$, Bose J. Salt stress sensing and early signalling events inplant roots: Current knowledge and $\begin{array}{llll}\text { hypothesis. } & \text { Plant } & \text { Sci. } & \text { 2015;241:109-19. }\end{array}$ https://doi.org/10.1016/j.plantsci.2015.10.003

27. Chawla S, Jain S, Jain V. Salinity induced oxidative stress and antioxidant system in salt tolerant and salt sensitive cultivars of rice (Oryza sativa L.) J Plant Biochem Biotechnol. 2013;22(1):27- 34. https://doi.org/10.1007/s13562-012-0107-4

28. Gill SS, Tutej N. Reactive oxygen species and antioxidant machinery in abiotic stress tolerance in crop plants. Plant Physiol Biochem. https://doi.org/10.1016/j.plaphy.2010.08.016 2000;48:909-30

29. Wang Y, Li X, Li J, Bao Q, Zhang F, Tulaxi G. Wang Z. Saltinduced hydrogen peroxide is involved in modulation of antioxidant enzymes in cotton. The Crop Journal. 2016;4:49098. https://doi.org/10.1016/j.cj.2016.03.005

30. Jalali P, Navabpour S, Yamchi A, Soltanloo H, Bagherikia S. Differential responses of antioxidant system and expression profile of some genes of two rice genotypes in response to salinity stress. Biologia.

2019;1-9 https://doi.org/10.2478/s11756-019-00393-x

31. Salwa AO, Mona GD, Salman SR. Comparative study between the physiological role of hydrogen peroxide and salicylic acid in alleviating the harmful effect of low temperature on tomato plants grown under sand ponic culture. Sci Agric. 2015;9:4959. https://doi.org/10.15192/PSCP.SA.2015.1.9.4959

32. Sofo A, Scopa A, Nuzzaci M, Vitti A. Ascorbate peroxidase and CAT activities and their genetic regulation in plants subjected to drought and salinity stresses. Int J Mol Sci. 2015;16:1356178. https://doi.org/10.3390/ijms160613561

33. Davey MW, Stals E, Panis B, Keulemans J, Swennen RL. Highthroughput determination of malondialdehyde in plan tissues. Anal Biochem. 2005;347:201-07. https://doi.org/10.1016/ j.ab.2005.09.041

34. Bor M, Ozdemir F, Turkan TO. The effects of salt stress on lipid peroxidise and antioxidants in leaves of sugar beet, Beta vulgaris L. and wild beet Beta maritime L. Plant Science. 2003;164(1):77-84. https://doi.org/10.1016/S0168-9452(02)003382

35. Mallick S, Sinam G, Sinha S. Study on arsenate tolerant and sensitive cultivars of Zea mays L.: differential detoxification mechanism and effect on nutrients status. Ecotoxicology and Environmental Safety. 2011;74(5),1316-24. https://doi.org/10.1016/j.ecoenv.2011.02.012

36. Scandalios JG. Molecular genetics of superoxide dismutase in plants In: Scandalios JG (editor) Oxidative Stress and Molecular Biology of Antioxidant Defences (Cold Spring Harbor Laboratory Press, New York). 1997; pp.527-68.

37. Corpas F, Gomez JM, Hernandez JA, Del-Rio JA. Metabolism of activated oxygen in leaf peroxisomes from two Pisum sativum L. cultivars with different sensitivity to sodium chloride. Plant Physiol. 1993;141:160-65. https://doi.org/10.1016/S01761617(11)80753-4

38. Noctor G, Foyer C. Ascorbate and Glutathione: Keeping active oxygen under control. Annual Review of Plant Physiology and $\begin{array}{llll}\text { Plant } & \text { Mol } & \text { Biol. } & \text { 1998;49:249-79. }\end{array}$ https://doi.org/10.1146/annurev.arplant.49.1.249

39. Hasanuzzaman M, Nahar K, Anee TI, Fujita M. Glutathione in plants: biosynthesis and physiological role in environmental stress tolerance Physiol Mol Biol Plants. 2017;23:249-68. https://doi.org/10.1007/s12298-017-0422-2

40. Li J, Hu L, Zhang L, Pan X, Hu X. Exogenous spermidine is enhancing tomato tolerance to salinity-alkalinity stress by regulating chloroplast antioxidant system and chlorophyll metabolism. BMC Plant Biology. 2015;15(1):303. https://doi.org/ 10.1186/s12870-015-0699-7

41. Mittova V, Guy M, Tal M, Volokita M. Response of the cultivated tomato and its wild salt tolerant relative Lycopersicon pennelli to salt dependant oxidative stress: Increased activities of antioxidant enzymes in root plastids. Free Rad. Res 2002;36(2):195-202. https://doi.org/10.1080/10715760290006402

42. Bleau G, Giasson C, Burnette I. Measurement of Hydrogen peroxide in biological samples containing high levels of ascorbic acid. Ann Biochem. 1998;263:13-17. https://doi.org/10.1006/abio.1998.2801

43. El-Shabrawi H, Kumar B, Kaul T, Reddy MK, Singla-Pareek SL, Sopory SK. Redox homeostasis, antioxidant defense and methylglyoxal detoxification as markers for salt tolerance in Pokkali rice. Protoplasma. 2010;245:85-96. https://doi.org/10.1007/s00709-010-0144-6 